\title{
DELINEATING PROTECTION AREAS FOR CAVES USING CONTAMINATION VULNERABILITY MAPPING TECHNIQUES: THE CASE OF HERRERÍAS CAVE, ASTURIAS, SPAIN
}

\author{
A.I. Marín ${ }^{1}$, B. Andreo ${ }^{1}$, M. Jiménez-SÁncheZ², M.J. Domínguez-Cuesta², And \\ M. MelÉndeZ-ASENSIO2,3
}

\begin{abstract}
Diverse approaches are adopted for cave protection. One approach is delineating protection areas with regard to their vulnerability to contamination. This paper reports the main results obtained from the delineation of a protection zone for Herrerías Cave, declared of Cultural Interest by the Asturias Regional Government, based on assessing its vulnerability to contamination. The cave is situated in a complex karst hydrogeologic environment in which groundwater flows from southwest to northeast, following the bedrock structure. A stream flows inside the cave, emerging in a spring located to the northeast of the system. Karst recharge occurs by direct infiltration of rainfall over limestone outcrops, concentrated infiltration of surface runoff in the watershed draining the cave, and deferred infiltration of water from alluvial beds drained by influent streams. The soil and vegetation covers are natural in the majority of the test site, but land uses in the watershed, including scattered farming, stock breeding, quarrying, and tourist use, are changing the natural characteristics and increasing the cave's vulnerability to contamination. The procedure followed for delineating protection zones is based on the method $\mathrm{COP}+\mathrm{K}$ that is specifically designed for vulnerability mapping of groundwater springs in carbonate aquifers. To cover the hydrological basin included in the cave's catchment area, the protection zones established includes two different areas, the hydrogeological catchment basin and adjacent land that contributes runoff. Different degrees of protection in the zones have been proposed to make human activity compatible with conservation of the cave, and our results show remarkable differences from the protection zone previously proposed for the same area.
\end{abstract}

\section{INTRODUCTION}

There is increasing public concern today regarding the protection of our natural heritage. Caves represent an outstanding, unique element in the natural landscape and are sometimes the economic driving force of regions dependent on tourism, and they may also motivate the creation of protected areas, as for example, Škocjan Caves Regional Park, Slovenia (Official Gazette of the Republic of Slovenia, 801-07/94-5/3, 1996) and Ardèche Gorge Natural Reserve, France (Statutory order $n^{\circ} 80-27,14$ January 1980). There are different ways of extending official protection to caves. In Europe, one method is declaration as a Site of Community Interest or an Area of Special Conservation Interest. This is possible when the cave is not open to tourism and protection is necessary to maintain or restore an environment for animal or plant species of community interest that require strict protection, such as bat species listed in the Habitats Directive of the European Union, 92/43/CEE. In other cases, the cave importance may be linked to the presence of archaeological remnants, motivating its declaration as part of the national cultural heritage, or even as a World Heritage Site. For example, Altamira Cave was awarded this distinction by UNESCO (SC.85/CONF.008/09, 1985).

Conservation, evaluation, and management are frequently performed by local administrations, regional or national departments of culture, or international agencies. Thus, the United Nations has promoted different initiatives specifically focused on the protection of cultural heritage. However, these efforts are mainly aimed at restoration and conservation and rarely focus on damage prevention (Catani et al., 2002).

The underground extent of caves is usually not apparent from the surface, and this sometimes leads to damage being done unwittingly. Since caves form part of karst aquifers, the possibility of such damage is influenced by the hydrogeological characteristics of karst environments that are especially vulnerable to contamination (Zwahlen, 2004). An example is given by Slovenia, a

\footnotetext{
${ }^{1}$ Centre of Hydrogeology (CEHIUMA) and Department of Geology, University of Málaga, Spain aimarin@uma.es andreo@uma.es

${ }^{2}$ Department of Geology, University of Oviedo, Spain mjimenez@geol.uniovi.es, mjdominguez@geol.uniovi.es

${ }^{3}$ Spanish Geological Survey, Oviedo Office, Spain m.melendez@igme.es
} 


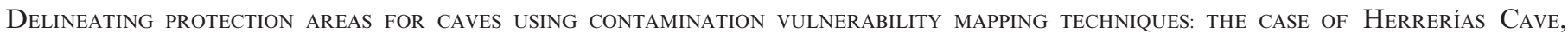
Asturias, Spain

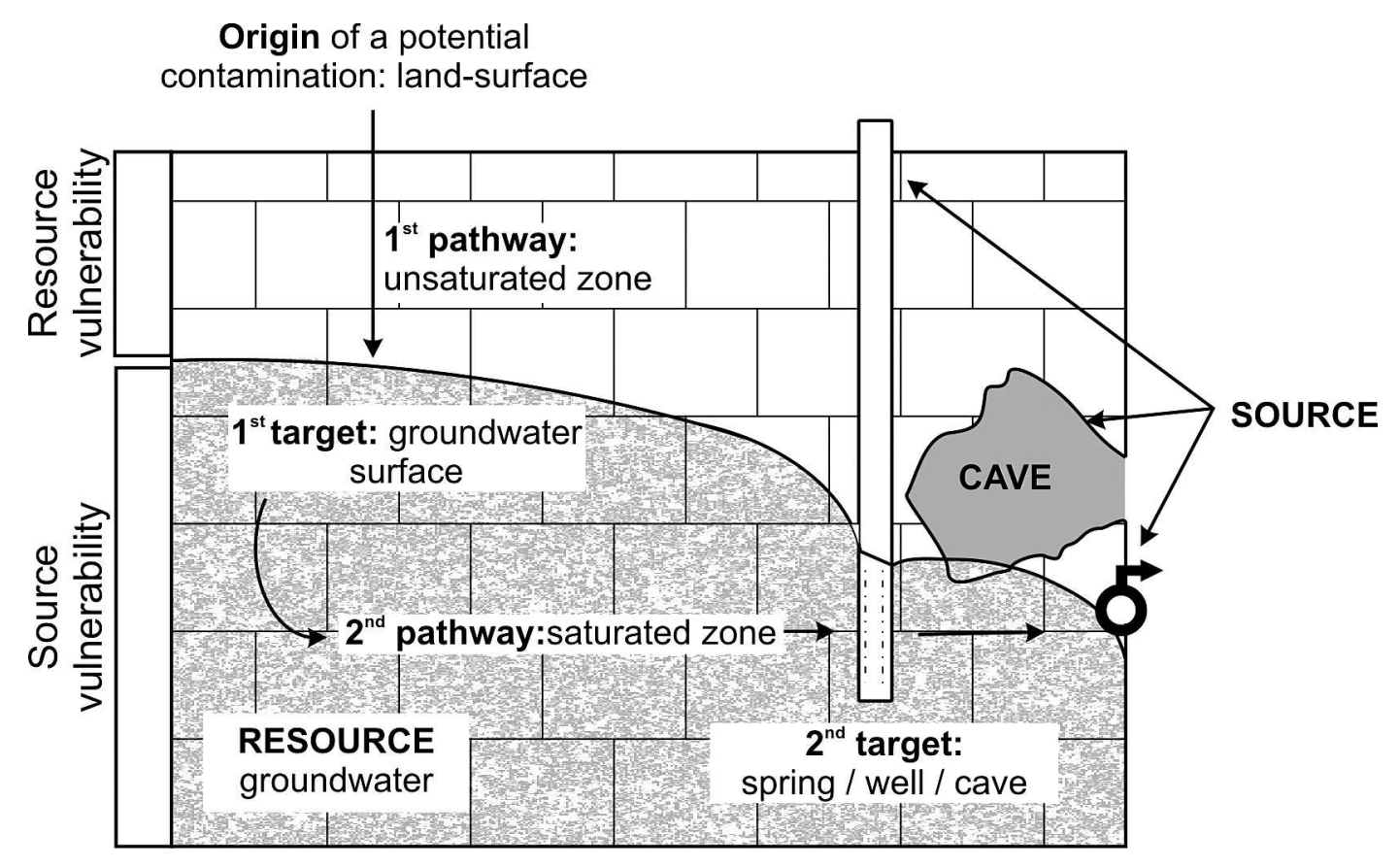

Figure 1. Diagram of the origin-flow-target conceptual model, proposed in European COST Action 620 (modified from Goldscheider in Zwahlen, 2004).

country with a long tradition of karst conservation, where the first measure for cave protection dates from 1908 (Badiura and Brinšek) and in which approximately $20 \%$ of the 7405 caves recorded in the 2001 Cave Survey have been contaminated as a consequence of human activity (Kepa, 2001).

In recent years, spurred by the work of international agencies such as UNESCO, there has been an increase in legislation and practical work focusing on prevention of damage to the cultural and natural heritage. At the 32nd UNESCO Convention Concerning the Protection of the World Cultural and Natural Heritage, warnings of the risks faced regarding the conservation of caves were made: "In the context of contemporary discovery and opening of caves, complex risks have arisen related to the alteration of the physical, geological and biological conditions of conservation" and "Extremely rigorous management is required to ensure that the risks are effectively dealt with" (WHC-08/32.COM/24 Rev, 2009). Nevertheless, as yet no rules have been clearly defined in legislation regarding what kinds of measures should be taken and how protected areas should be defined to protect caves and their surroundings. In many cases, protection is limited to preventing entry into the cave, an insufficient measure that often fails (Lera, 2009). Moreover, the complexity and diversity of the karst medium hampers the design of a universal method of establishing protected areas for caves and their surroundings. Accordingly, any proposal should consider the identification and evaluation of the natural processes that involve risks to the conservation of the cave. In addition, it will be necessary to consider human activities such as construction, livestock farming, and agriculture that could have a negative impact on the natural evolution of caves (Sánchez-Moral et al., 2002).

Evaluating the vulnerability of a cave to contamination, on the basis of the characteristics of the physical medium in which it is contained, can be used to promote land-use management that is compatible with the protection and conservation of the cave. This approach is an initial step in the delineation of protection zones for the cave and in preventing the risk of contamination. Furthermore, a good plan for the protection and conservation of a cave could include other studies, such as analysis of geological risks, particularly regarding its resistance to vibrations (Sánchez et al., 2007; Iriarte et al., 2010), the evaluation of human impact using quantitative indexes based on geomorphological features (Jiménez-Sánchez et al., 2011), and studies of the cave's environmental capacity with respect to the optimum number of visits permissible in tourist caves (Pulido-Bosch et al., 1997; Cuevas-González et al., 2010).

The concept of the contamination vulnerability of an aquifer has been defined by many investigators, among them Margat (1968) and Zaporožec (1994). The intrinsic vulnerability of an aquifer involves its sensitivity to contamination, taking into account its geological, hydrological and hydrogeological characteristics, independent of the nature of the contaminants and the contamination scenario (Zwahlen, 2004). This concept of intrinsic vulnerability, proposed in the European COST Action 620 , is based on the origin-flow-target conceptual model (Fig. 1). Using this model, it is possible to distinguish between resource protection and water supply protection. 

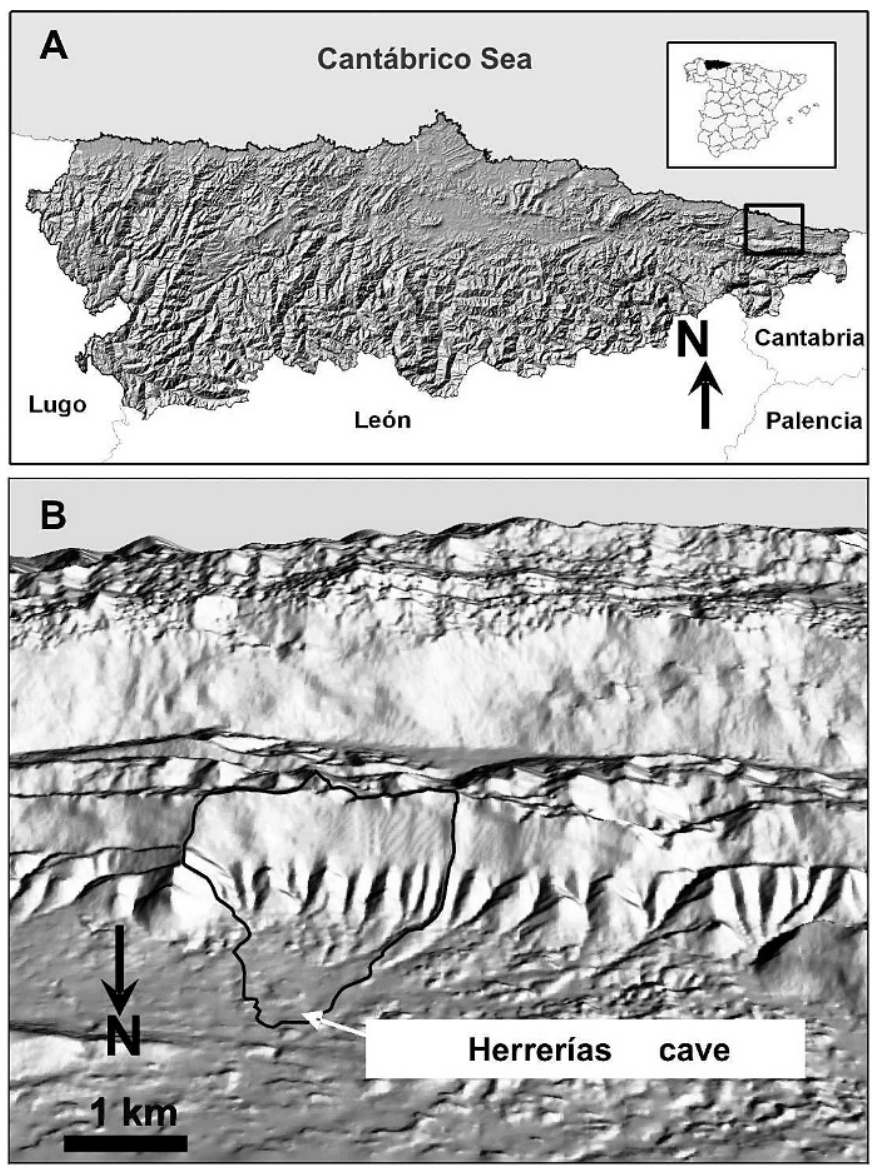

Figure 2. (A) Location of Herrerías Cave. (B) Site of cave and hydrological watershed over digital elevation model.

Considering resource protection, it is assumed that the element to be protected is the water stored in the aquifer below the piezometric surface. The flow of the polluting agent from the origin is considered to be practically vertical, passing through the soil and the unsaturated zone of the aquifer. In the case of source protection, the target of protection is the aquifer discharge point at a well or spring. Conceptually, the contaminant is assumed to be transported from the origin at the surface to the aquifer and from there to the discharge point at a spring or well. This displacement has a vertical component from the origin to the piezometric surface and a horizontal one, the latter being in the saturated zone of the aquifer.

The main aim of the present study is to adapt the groundwater-contamination vulnerability mapping method to the delineation of protection areas for caves close to the piezometric level or to a spring. The experimental site considered was the Herrerías Cave in northern Spain, for which a protection boundary has been established by the Culture and Tourism Department of the Asturias Regional Government (BOPA, 2008; BOE, 2010), permitting a comparison between this and the protection area established in present work.

\section{The Study Area}

The cave known as Herrerías, La Herrería, or El Boláu is situated in the district of Llanes in Asturias, Spain (Fig. 2). The cave contains valuable examples of prehistoric art that make it particularly interesting from a heritage point of view. The cave paintings consist of a set of grid forms composed of individual marks and parallel lines, located in the roof of the cave. The significance of the rock art, which is attributed to the Magdalenian (Jordá and Mallo, 1972), led to the cave's being declared a Good Object of Cultural Interest as a result of application of the 1985 Spanish Historical Heritage Law (BOE, 1985). The floor plan of the cave is intricate and irregular, with a horizontal extent of less than $200 \mathrm{~m}$ and two access points to a main gallery, the southwestern branch of which is blocked by a gate that protects the room containing the cave paintings. Land use surrounding the cave is characterized by scattered farming and stock breeding that coexist with tourist use. Also, the remnants of mining and quarrying works can be recognized in the landscape, including historic quarrying in the quaternary alluvial fans, as well as an old iron-manganese mine, located in the limestone to the west of the cave (Domínguez-Cuesta et al., 2010). The top of the karst massif in which the cave is located is presently covered by a building material dump, a potential source of cave contamination.

Herrerías Cave is located in a complex hydrogeological environment that governs its vulnerability to contamination events and thus, its need for protection. For this reason, a multidisciplinary study involving geological, geomorphological, and hydrogeological aspects have been done in a $10 \mathrm{~km}^{2}$ area, including the cave's surroundings (Jiménez-Sánchez et al., 2010).

The landscape surrounding the cave contains mountainous ranges and valleys trending east-west, following the geological contacts between bedrock formations. Altitudes descend from the mountainous ranges in the south (Sierra del Cuera, 1315 meters above sea level) to the vicinity of the Cantabrian shore to the north, where remnants of karstified marine terraces can be recognized between 30 and 189 masl. The hydrographic network is superimposed on this relief, with streams mainly flowing from south to north, giving place to torrential basins and coalescing alluvial-fan deposits. Herrerias Cave is located at the bottom of one of these torrential basins, which shows a total surface of $3.37 \mathrm{~km}^{2}$, a mean slope of $23^{\circ}$ (maximum of $57^{\circ}$ ), and altitudes ranging between $34 \mathrm{~m}$ and $757 \mathrm{~m}$ (Fig. 2b).

Geologically, the study area is located in the PongaCuera Unit (Marquínez, 1989). The stratigraphic sequence is composed of Barrios quartzite of the Ordovician age, the Ermita sandstone of Late Devonian age, and several Carboniferous limestone formations: the Alba, Barcaliente, and Cuera that outcrop trending east-west, showing subvertical dips (Figs. 3 and 4). The most outstanding 


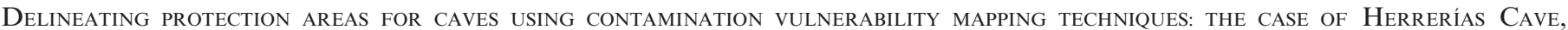
Asturias, Spain

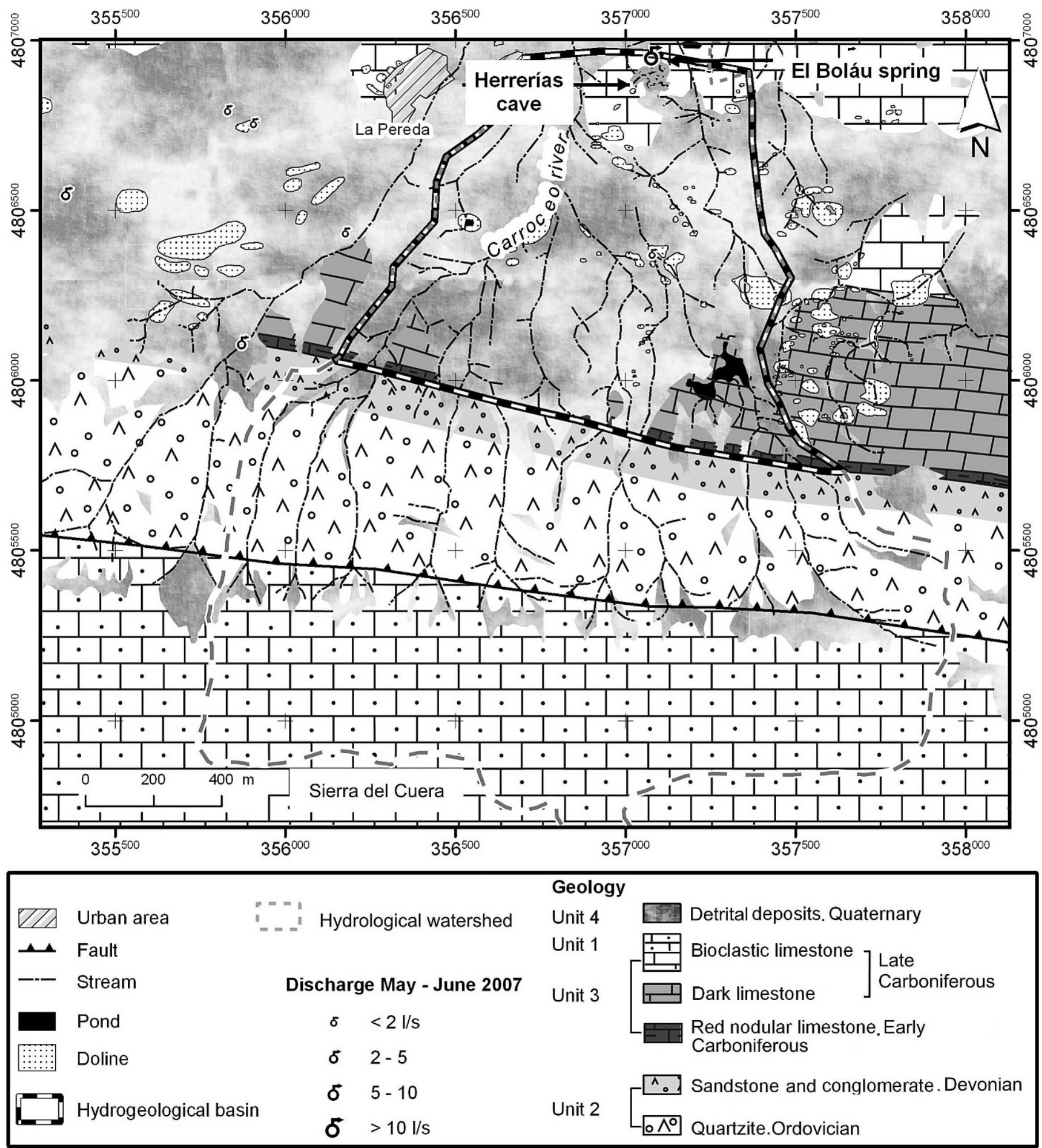

Figure 3. Geological-hydrogeological map of Herrerías Cave and its surroundings.

structure is a subvertical thrust, also trending east-west, that puts Ordovician quartzite in contact with the Cuera limestone to the south. The cave is developed in a region of Cuera limestone located in the north of the study area. The
Paleozoic bedrock is covered by several Quaternary formations of alluvial, colluvial, and karstic origin.

Four hydrogeologic units can be distinguished in the study area (Figs. 3 and 4), from south to north: Unit 1 


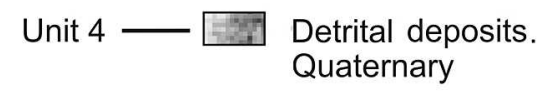

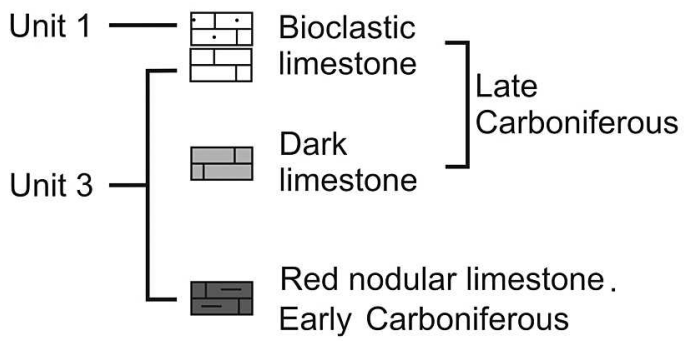

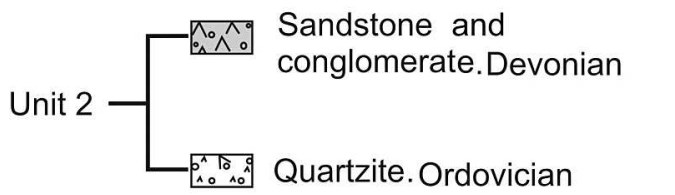

No to scale

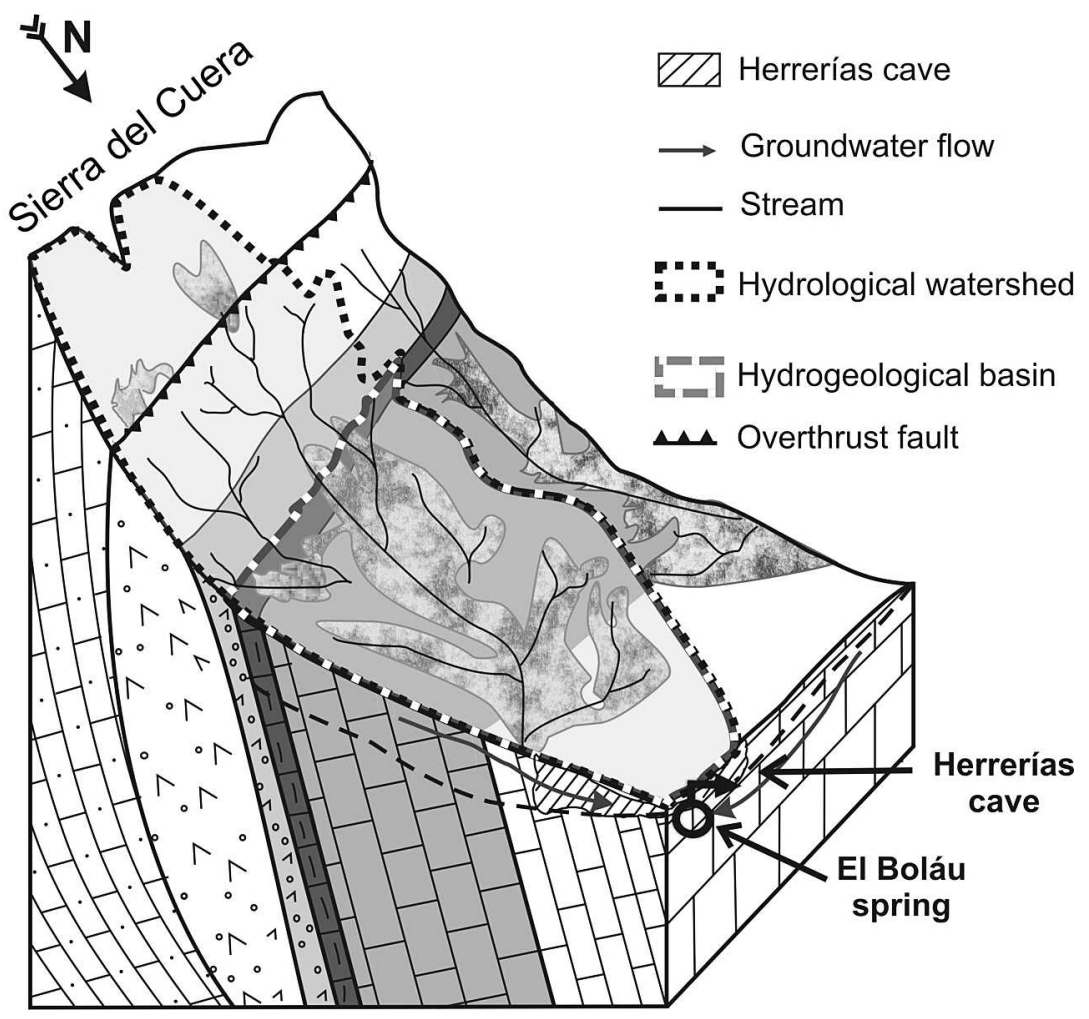

Figure 4. Geological-hydrogeological diagram of Herrerías Cave and its surroundings.

comprises the Cuera limestones; Unit 2 consists of Ordovician quartzite and Devonian sandstone and is separated of Unit 1 by a thrust fault; Unit 3 contains Carboniferous limestone of the Cuera and Barcaliente Formations. Finally, Unit 4 is characterized by Quaternary alluvial materials that lie unconformably over the bedrock formations (Jiménez-Sánchez et al., 2008a). Units 1 and 3, made up of karstifiable limestone, are carbonate aquifers; Herrerías Cave is located in Unit 3, to the north of the thrust fault (Figs. 3 and 4). The Ordovician quartzite and Devonian sandstone constitute a barrier that prevents the underground connection between the two carbonate aquifers (Ortuño et al., 2004; Fig. 4).

The Units 1 and 2 form part of the recharge area of the aquifer in which the cave is located (Unit 3), because part of the surface area drains toward this aquifer via numerous streams. Unit 3, with a groundwater flow northward, is drained by springs, including that of El Boláu, which is the resurgence of this cave. The groundwater flow into the cave takes place through multiple drip points and via a subterranean watercourse that is visible in some areas in the cave. Thus, as shown in Figures 2 and 3, in the study area the hydrological watershed and hydrogeological basin do not coincide.

From the above observations, it can be deduced that the recharge area of both El Boláu spring and Herrerías Cave, contains two different sectors. The southern sector constitutes the limestone of Unit 1 and the sandstone and quartzite of Unit 2. Surface runoff generated in this sector infiltrates into the aquifer limestones farther north in Unit 3 through the overlying Quaternary deposits of Unit 4. Therefore, the influence of the southern sector on the cave's vulnerability to contamination is related to the infiltration of surface water and potential contaminants from the hydrological watershed. The connection between certain points of this hydrographic network and the cave has been demonstrated by the injection of sodium fluoresceine into the Carroceo River (Jiménez-Sánchez et al., 2010).

The northern sector is the part of the aquifer containing the Unit 3 limestone that drains toward the El Boláu spring. Despite the lack of data on piezometric levels, it seems reasonable to believe that the El Boláu spring drains water directly infiltrating into the limestones outcrops (Unit 3), together with the infiltration water from surface runoff from the southern areas. In addition to these two components, there is recharge from the Quaternary materials of Unit 4, as also demonstrated by tracer injection in the Carroceo River (Jiménez-Sánchez et al., 2010).

Analyses of water samples collected at a drip point in the cave during the months of February-June 2007 show that the evolution of the $\mathrm{NO}_{3}^{-}, \mathrm{NO}_{2}^{-}$, TOC (total organic carbon) and $\mathrm{Cl}^{-}$content is related to recharge episodes, but also to contamination from human activities in the area of the cave's recharge zone. Peaks of $20 \mathrm{mg} \mathrm{L}^{-1}$ and 


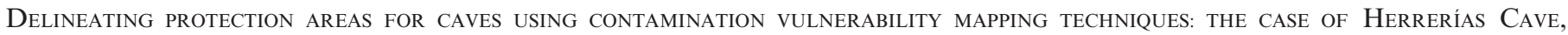
Asturias, Spain

$50 \mathrm{mg} \mathrm{L}^{-1}$ of TOC, $15.63 \mathrm{mg} \mathrm{L}^{-1}$ of $\mathrm{NO}_{3}^{-}$and $\approx 17 \mathrm{mg} \mathrm{L}^{-1}$ of $\mathrm{NO}_{2}^{-}$have been detected in the drip water (JiménezSánchez et al., 2008b).

\section{Application of the COP+K Method}

In this study, the $\mathrm{COP}+\mathrm{K}$ method (Vías et al., 2006; Andreo et al., 2009) was applied. This method was originally developed to evaluate contamination vulnerability and to delineate protection areas for water supply springs or wells in carbonate (karst) aquifers. However, this method must be reinterpreted and specifically adapted to this case, considering Herrerías Cave itself is a protection target (Fig. 1), in a way analogous to that applied to water supply sources.

The $\mathrm{COP}+\mathrm{K}$ method is an extension of the COP method (Vías et al., 2006), by which the contamination vulnerability of karstic aquifers can be evaluated and on the basis of this assessment, protection zones defined. This method incorporates the conceptual model and the indications set out in the framework of European COST Action 620 (Zwahlen, 2004). The COP+K method is based on estimating the surface flow recharge conditions ( $\mathrm{C}$ factor), the protection capacity of the layers overlying the aquifer ( $\mathrm{O}$ factor), and the precipitation ( $\mathrm{P}$ factor), together with the participation of the saturated zone ( $\mathrm{K}$ factor). The method is applied using cartographic overlay created with geographic information systems. The procedure, classification, and scoring of the variables used to evaluate vulnerability according to the $\mathrm{COP}+\mathrm{K}$ method are shown in Fig. 5 and explained in detail by Vías et al. (2006) and Andreo et al. (2009).

In accordance with current knowledge of the hydrogeological system of Herrerías Cave and its surroundings (Jiménez-Sánchez et al., 2008a, 2008b, 2010), the protection of the cavity should consider both surface water in the hydrological watershed and groundwater in the hydrogeological basin (Figs. 3 and 4). However, application of the $\mathrm{COP}+\mathrm{K}$ method is only possible in the hydrogeological basin of the Herrerías Cave, where there is a vulnerable carbonate aquifer and deposits of alluvial materials (Units 3 and 4, Fig. 2). Since Unit 2 (Ordovician quartzites and Devonian sandstones) does not constitute an aquifer, it is not possible to evaluate the thickness of the unsaturated zone ( $\mathrm{O}$ factor) or the transit through the saturated zone of possible contaminants ( $\mathrm{K}$ factor). Likewise, no valuation is made of the $\mathrm{K}$ factor (transit through the saturated zone) in Unit 1 because, as remarked above, this unit has no hydrogeological connection with the cave. The main results of our evaluation of the parameters composing the method are described below (Fig. 6).

\section{FACTOR}

This factor was the most difficult one to assess, due to the double component of runoff and infiltration acting as recharge and to the non-coincidence of the hydrological and hydrogeological watersheds. The surface conditions for the concentration of water flows to recharge the aquifer (the $\mathrm{C}$ factor) were evaluated based on a prior classification of the study area into the two infiltration sources defined in the original method, concentrated infiltration via karstic swallow holes and direct infiltration of rainfall over outcrops in the rest of the catchment (Vías et al., 2006). However, an additional source of infiltration affects a significant sector of the study area, deferred infiltration through the beds of influent streams that was demonstrated by the use of tracers at certain points (Jiménez-Sánchez et al., 2010). Evaluation of the $\mathrm{C}$ factor of this new source was carried out using an adaptation of the two scenarios previously defined by Vías et al. (2006). The scores of the sv, dh, and ds subfactors were modified (see Tables XII$\mathrm{XIV}$ in Fig. 5; scenario 3 of $\mathrm{C}$ factor), taking into account that this infiltration through the unsaturated zone is concentrated, but not as much as in sinking streams via swallow holes.

\section{O FACTOR}

The spatial distribution of the protection capacity of the layers overlying the aquifer in which Herrerías Cave is developed reflects the distribution of the soil that is important in protecting groundwater against contamination episodes. Above this aquifer, the soil is the only layer conferring heterogeneity to the $\mathrm{O}$ factor, as the lithology is similar throughout the hydrogeological basin to be delineated. The protection capacity is very low immediately surrounding of the cave because the soil is practically nonexistent. The protection capacity is slightly higher in the rest of the hydrogeological basin where the soil is better developed, and it has been even considered high in the small areas where soil of a clayey texture and greater thickness has been mapped.

\section{P FACTOR}

This factor was evaluated using data obtained from the Parres de Llanes meteorological station, located $1.3 \mathrm{~km}$ northwest of the cave. The $\mathrm{P}$ factor is based on the quantity and intensity of precipitation events based on the daily precipitation of a historical set of wet years. The average rainfall is $1600 \mathrm{~mm}$ and the average number of days of rain per year is 135 . This annual precipitation helps in the dilution of potential contaminant that is likely to be dominant process instead of infiltration (Vías et al. 2006). A moderate reduction in the level of protection provided by the unsaturated zone (evaluated by $\mathrm{O}$ factor) due to the precipitation characteristics in this area has been identified. This parameter was taken as homogeneous for the test site (Fig. 6) because of the lack of an adequate number of meteorological stations. Although this factor does not influence the distribution of vulnerability classes, it affects the indexes of vulnerability, reducing the value resulting from the $\mathrm{C}$ and $\mathrm{O}$ factors; the value of $\mathrm{P}$ factor is 0.7 . 


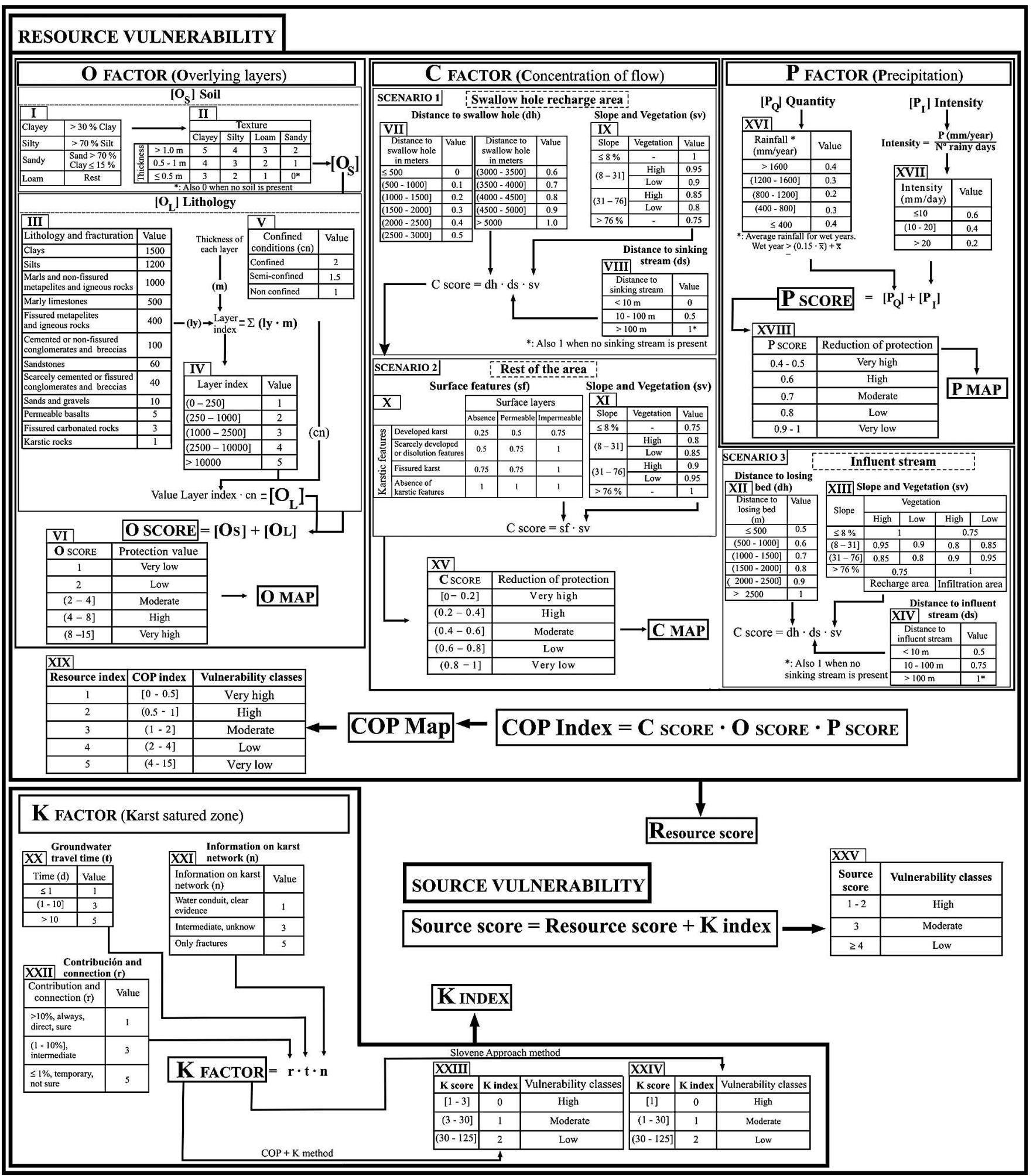

Figure 5. Diagram of the $\mathrm{COP}+\mathrm{K}$ method, showing the differentiation of the $\mathrm{C}, \mathrm{O}, \mathrm{P}$, and $\mathrm{K}$ factors. Modified from Vías et al. (2006).

The COP vulnerability index map (COP in Fig. 6), is the cartographic overlay of the $\mathrm{C}, \mathrm{O}$, and $\mathrm{P}$ factors and shows the vulnerability to contamination of the test site. The aquifer in which Herrerías Cave is located presents a contamination vulnerability level ranging from high to very high. In only a few small sectors is the vulnerability classified as moderate. The distribution of the areas where contamination vulnerability is very high is determined by 


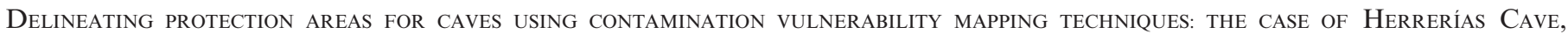
Asturias, Spain
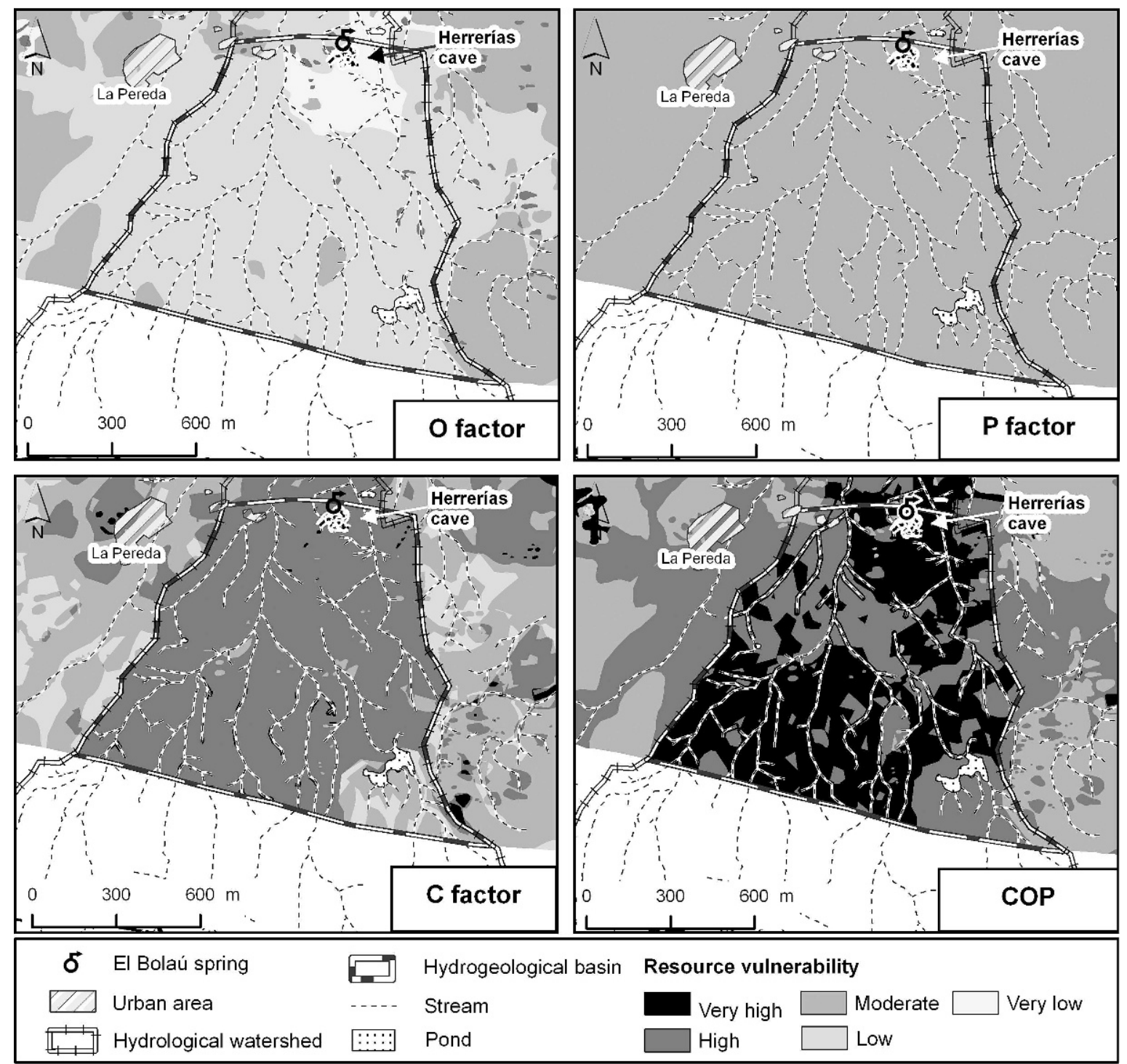

Figure 6. C, O, P, and COP maps assessing the vulnerability of the areas surrounding Herrerías Cave.

two factors: the scant protection capacity afforded by the layers overlying the aquifer (very low $\mathrm{O}$ factor values) and the considerable reduction of the protection capacity resulting from the concentration of surface runoff flows provoking infiltration (the $\mathrm{C}$ factor). Only where the slope is lower than $8 \%$ is the resource vulnerability on the hydrological watershed high instead of very high. In the COP index map in Figure 6, the watershed area fed by influent streams shows values of vulnerability higher than those obtained in similar areas out of this hydrographic basin.

\section{K FACTOR}

This factor was evaluated after determining the direction and velocity of groundwater flow in the study area using tracer tests and other hydrogeologic criteria. Specifically, three flow velocities were determined (Fig. 7).
Between Meandros Hall and Pinturas Hall in the cave, the approximately east to west flow velocity was $128 \mathrm{~m} \mathrm{~h}^{-1}$, while between Pinturas Hall and the El Boláu spring, it ranged from 237 to $250 \mathrm{~m} \mathrm{~h}^{-1}$ in an approximately northeasterly direction (two tracer tests; Jiménez-Sánchez et al., 2010). The tracer tests were carried out in a small sector of the hydrogeological basin, and so their ability to represent the entire aquifer remains uncertain until additional data are acquired to improve the $\mathrm{K}$ factor evaluation. The difference in velocities calculated using the tracer tests has no impact on the application of the $\mathrm{COP}+\mathrm{K}$ method because the entire study area has a transit time (the $t$ subfactor in the method) of less than one day. The $r$ subfactor considers the contribution and connection rates of different parts of the aquifer to the cave. The overall hydrogeological basin was considered directly connected to the cave. 


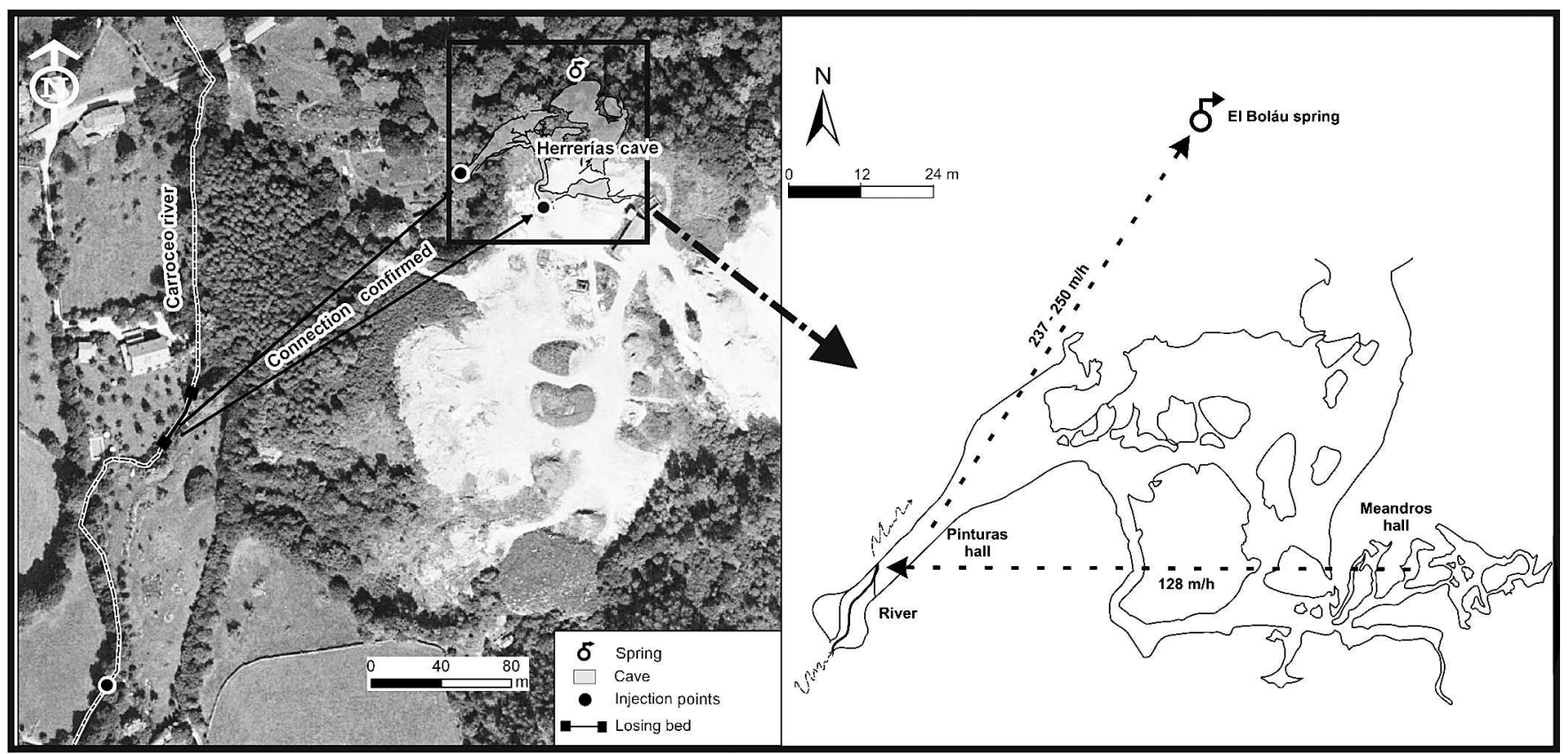

Figure 7. Sketch of the tracer tests to and within Herrerías Cave and the flow velocities deduced.

With respect to the karst network (subfactor $\mathrm{n}$ in the $\mathrm{COP}+\mathrm{K}$ method), the cave is a conduit in which the piezometric level is visible in some sectors. However, as the cave itself is the object of protection, the water route considered is solely that from the surface to the walls and roof of the cave. Once the water or the potential contaminant reaches the cavity walls, the flow has reached the objective (Fig. 8). Water transit through the cave was not considered for the purposes of delineating the protection boundary.

The $\mathrm{K}$ value is the product of the three subfactors described above, the $t, r$, and $n$ subfactors. $K$ values can be subdivided into three classes, indicating different degrees of vulnerability of a water source to contamination. This enables the class boundary values to be modified in response to legislation passed to protect water supply sources (Fig. 5). For example, according to the Slovene approach (Ravbar and Goldscheider, 2007) vulnerability is high only when the $\mathrm{K}$ value is 1 ; in areas where the transit time is less than 1 day, there is clear evidence of an active karst network and the contribution rate is $>10 \%$. However, for a given source, according to the methodology proposed by Andreo et al. (2009), values of 1 to 3 indicate high vulnerability to contamination. Many carbonate

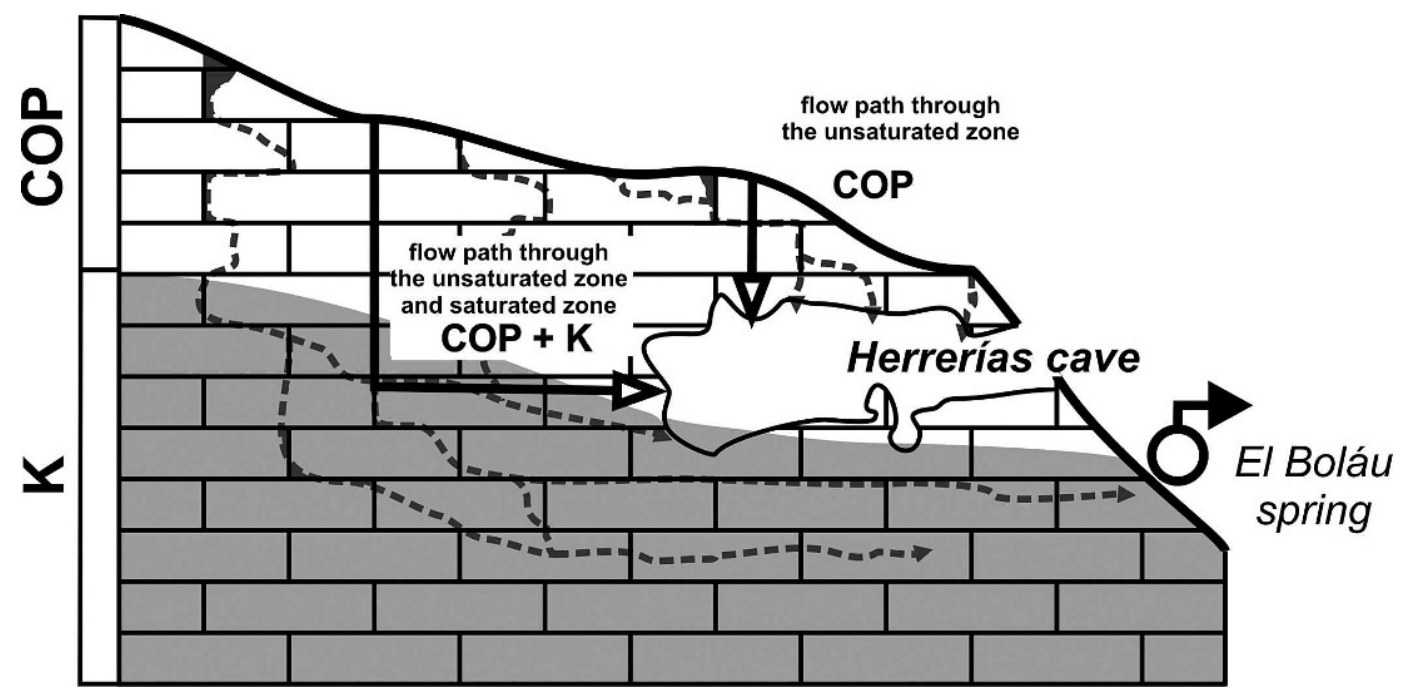

Figure 8. Conceptual diagram of the transit of possible contaminants toward Herrerías Cave. 
aquifers present good permeability as a result of the development of conduits enabling rapid flow velocities and direct connections. However, these aquifers might not have been identified or explored, and so a lower subfactor $n$ value would not be awarded. In such a case, which is very similar to the study area conditions, the $\mathrm{K}$ factor would represent a high level of vulnerability in accordance with the $\mathrm{COP}+\mathrm{K}$ classification, and a moderate one according to the Slovene approach.

\section{InTRinsic Source Vulnerability MaP}

By converting the $\mathrm{COP}$ and $\mathrm{K}$ values into their respective indices and summing them (Fig. 5), we obtain the source (the cave) contamination vulnerability map. By direct interpretation of the vulnerability classes, it is possible to find the areas that need various degrees of protection (Andreo et al., 2009). The vulnerability map for the Herrerías Cave obtained using the $\mathrm{COP}+\mathrm{K}$ method, classifying the $\mathrm{K}$ factor according to the Slovene approach ( $\mathrm{K}$ index $=1$, Table XXIV in Fig. 5), shows a large zone classed as highly vulnerable, coinciding with the areas where the resource vulnerability is considered very high (Fig. 6). These areas are located immediately surrounding the cave and in other sectors with aquifer recharge via influent streams (Marín et al., 2010). The vulnerability is considered moderate in areas where the resource vulnerability is high (COP index $=2)$ due to, especially, slopes that decrease flows towards influent streams. The cave's vulnerability to contamination, evaluated using the $\mathrm{COP}+\mathrm{K}$ method, with the $\mathrm{K}$ factor being scored using the $\mathrm{COP}+\mathrm{K}$ method $(\mathrm{K}$ index $=0$, Table XXIII in Fig. 5), is considered high in almost the entire hydrogeological basin. The vulnerability is moderate only in zones where soil and Quaternary materials offer a certain degree of protection, the zones where resource vulnerability is moderate (fig. 6). In any case, the results obtained demonstrate that Herrerías Cave shows a high level of vulnerability to contamination as a consequence of the physical characteristics and dynamics of the hydrogeological basin.

\section{Delineation of the Protection Zone}

The ultimate aim of the protection zoning is to protect the cave against possible negative impacts arising from human activity. The arrival of contaminant substances with infiltration water may provoke alterations within the cave environment. The entire area connected to the cave via flows of surface water or groundwater should be considered a possible site of contaminating activities, and therefore, should be included within the design of the protection boundary for the cave.

In the application of the $\mathrm{COP}+\mathrm{K}$ method to protection zoning, the areas taken into consideration were those classed as high vulnerability, requiring maximum protection, and moderate vulnerability, requiring a moderate degree of protection. The two maps proposed in Figure 9 illustrate the need for a protection boundary for this cave that includes the entire hydrological basin, independent of the degree of internal protection.

For comparison, Figure 9 shows the protection area published in the BOPA (2008) and BOE (2010) together with the one proposed in this study. The areas that we propose here as requiring maximum protection are larger than those defined in BOPA (2008) and BOE (2010) and include part of the watershed that feeds the influent streams. This network of influent streams on the northfacing slopes of the Sierra del Cuera merits special attention because of its hydrologic relation with the aquifer in which the cave is located. As explained above, in this area, surface runoff takes place, especially over the sandstones and quartzite of Unit 2. This surface runoff infiltrates downstream into the aquifer (Figs. 2 and 3). The maps presented in Figure 9 show that most of the river beds into which water infiltrates are located in the zone requiring maximum protection; therefore, any human use of the watershed should be controlled to avoid dumping or spills that, transported by the runoff water, could affect the cave. Accordingly, the hydrogeological basin fed by these rivers is considered part of the cave's protection zoning in a category we term watershed to control. Finally, unlike the perimeter defined in the BOPA and BOE, we do not consider it necessary to include the areas located to the north of the cave and El Boláu spring in the protection zone. The reason is that the water flow toward the north prevents any contaminant deposited in this zone from affecting the cave.

\section{Conclusions}

Protection zoning for caves is a preventive mechanism of great interest for their conservation. In the case of karst aquifers, this delineation goes beyond the simple marking out of zones requiring different degrees of protection in the immediate surroundings of the item to be protected, a spring, well, or cave. The hydrogeological characteristics of the surroundings should be considered in the process by which protection areas are defined. Therefore, in this study we adapted the $\mathrm{COP}+\mathrm{K}$ method, which is specific for groundwater contamination vulnerability assessment in carbonate aquifers.

The results obtained from applying this method to the Herrerías Cave show that protection measures need to consider the entire sector of the aquifer in which the cavity is located. Such protection zoning should include the riverbeds of influent streams and the corresponding hydrographic watersheds. Independently of the classification of the $\mathrm{K}$ factor, which concerns the karstification of the saturated zone, the extent of the protected areas established reveals the high degree of vulnerability to contamination of Herrerías Cave and the insufficiency of the current protection area defined for it. Land-use 


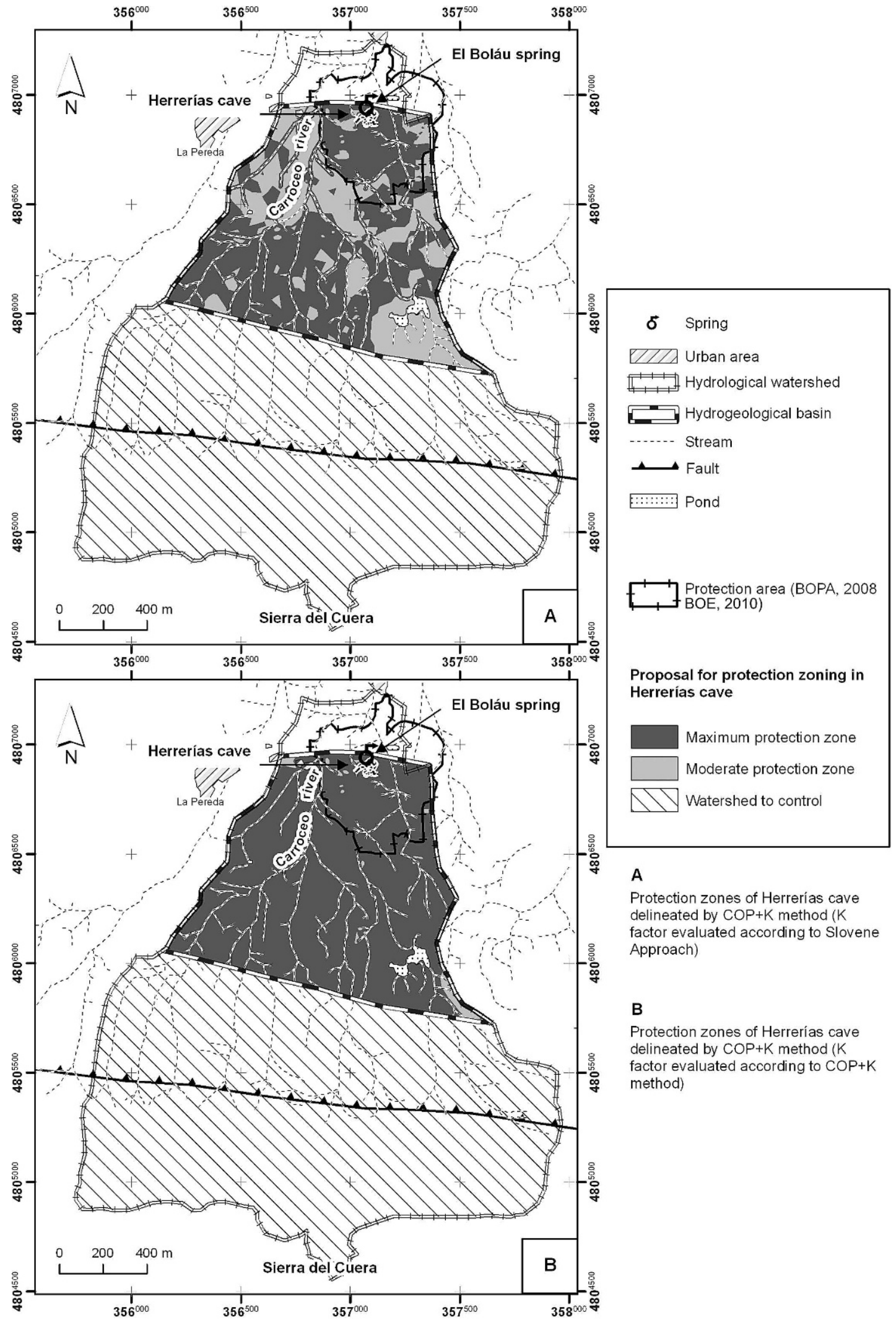

Figure 9. Protection areas proposed for Herrerías Cave on the basis of the contamination vulnerability evaluation made using the COP+K method (A) with the K factor being classified according to the Slovene approach (Ravbar and Goldscheider, 2007) and (B) with the $\mathrm{K}$ factor being classified using the $\mathrm{COP}+\mathrm{K}$ method (Andreo et al., 2009). Also shown is the protection area recommended in BOE (2010) and BOPA (2008). 


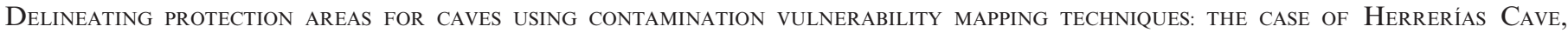
Asturias, Spain

planning is required to protect the cave. Spain has no national legislation defining the activities allowed in different protected areas. However, potentially polluting land-use activities should be prohibited or restricted, especially activities creating microbial contaminants and types of polluting land-use practices that generate dangerous leachates.

Apart from the final mapping obtained of the study area, the main contribution of this study is the adaptation of the $\mathrm{COP}+\mathrm{K}$ method to delineate cave protection areas, especially for caves containing groundwater flow or close to a spring. The evaluation of a cave's vulnerability to contamination, on the basis of the characteristics of the physical medium in which it is located, is a useful tool to ensure the compatibility of surface management and cave conservation. Hydrogeological studies are essential to achieve an adequate understanding of the interactions between the cave and its surroundings. The $\mathrm{COP}+\mathrm{K}$ method enables us to place this knowledge on a cartographic basis, which constitutes a good initial point for delineating cave protection areas and for preventing possible contamination.

Finally, it should be noted that protection areas are not static and need to be periodically reviewed to determine whether the physical variables justifying the delineation remain unchanged. If environmental alterations are detected or if further studies produced new information about hydrogeological relationships, the proposed perimeter should be reviewed and, if necessary, modified, in accordance with the new reality.

\section{ACKNOWLEDGMENTS}

This research has been partly supported by the Regional Government of Principado de Asturias (Contract CN-06177, University of Oviedo). It is a contribution to projects CGL2008-06158 BTE of the Spanish Ministry of Science and Higher Education and IGCP 513 of UNESCO, and to Research Group RNM-308 funded by the Regional Government of Andalusia (Spain). The authors thank M. Field (Editor-in-Chief) and B. Schwartz (Associate Editor), and anonymous reviewers for their constructive criticism.

\section{REFERENCES}

Andreo, B., Ravbar, N., and Vías, J.M., 2009, Source vulnerability mapping in carbonate (karst) aquifers by extension of the COP method: Application to pilot sites: Hydrogeology Journal, v. 17, no. 3, p. 749-758, doi:10.1007/s10040-008-0391-1.

Badiura, R., and Brinšek, B., 1908. Nove jame ob Cerkniškem jezeru. Planinski vestnik, p. 6-7, 96-99, 124-126, Ljubljana.

BOE, 1985, Ley 16/1985, de 25 de junio, del Patrimonio Histórico Español: Boletín Oficial del Estado, no. 155, p. 20342-20352.

BOE, 2010, Decreto 20/2010, de 3 de marzo, por el que se delimita el entorno de protección de la cueva de La Herrería, en La Pereda, en el concejo de Llanes: Boletín Oficial del Estado, no. 100, p. 36592-36594.

BOPA, 2008, Resolución de 27 de febrero de 2008, de la Consejería de Cultura y Turismo, por la que se aprueba el entorno de protección provisional para la cueva de La Herrería, en la Pereda, concejo de Llanes: Boletín Oficial del Principado de Asturias, v. 74, 7147 p.

Catani, F., Fanti, R., and Moretti, S., 2002, Geomorphologic risk assessment for cultural heritage conservation, in Allison, R.J., ed., Applied Geomorphology: Theory and Practice: West Sussex, England, John Wiley \& Sons, p. 317-334.

Cuevas-González, J., Fernández-Cortés, A., Muñoz-Cervera, M.C., Andreu, J.M., and Cañaveras, J.C., 2010, Influence of daily visiting regime in tourist cave at different seasons, in Andreo, B., Carrasco, F., Durán, J.J., and LaMoreaux, J.W., eds., Advances in Research in Karst Media, p. 475-481.

Domínguez-Cuesta, M.J., Jiménez-Sánchez, M., Rodríguez-Rodríguez, L., Ballesteros, D., Meléndez, M., Martos, E., and García-Sansegundo, J., 2010, Uso de la geomorfología y el SIG para caracterizar el impacto de actividades mineras en zonas kársticas: El entorno de la cueva de Las Herrerías (Asturias, España), in Berrezueta Alvarado, E., and Domínguez Cuesta, M.J., eds., Técnicas Aplicadas a la Caracterización y Aprovechamiento de Recursos Geológico-Mineros. Volumen I: Descripciones Metodológica: Oviedo, Spain, Instituto Geológico y Minero de España, p. 80-90.

Iriarte, E., Sánchez, M.A., Foyo, A., and Tomillo, C., 2010, Geological risk assessment for cultural heritage conservation in karstic caves: Journal of Cultural Heritage, v. 11, no. 3, p. 250-258, doi:10.1016/ j.culher.2009.04.006.

Jiménez-Sánchez, M., Domínguez-Cuesta, M.J., García-Sansegundo, J., Stoll, H., González- Pumariega, P., Fuente-Puente, G., Meléndez, M., Martos, E., Vadillo, I., Rodríguez-Rodríguez, L., and Aranburu, A., 2008a, Estudio preliminar de la geomorfología de la cueva de Herrerías y su entorno (Llanes, Asturias, Noroeste de España), in Benavente, J., and Gracia, F.J., eds., Trabajos de Geomorfología en España 2006-2008: Cádiz, Spain, Sociedad Española de Geomorfología and Universidad de Cádiz, p. 45-48.

Jiménez-Sánchez, M., Stoll, H., Vadillo, I., López-Chicano, M., Domínguez-Cuesta, M., Martín-Rosales, W., and Meléndez-Asensio, M., 2008b, Groundwater contamination in caves: Four case studies in Spain: International Journal of Speleology, v. 37, no. 1, p. 53-66.

Jiménez-Sánchez, M., Vadillo, I., Domínguez-Cuesta, M.J., Meléndez, M., Andreo, B., Marín, A.I., Stoll, H., Martos, E., GonzálezPumariega, P., Potenciano de las Heras, A., and García- Sansegundo, J., 2010, Estudio del karst en la cueva de las Herrerías y su entorno (Llanes, Asturias): Memoria final de investigación 2007-2010, Consejería de Cultura Principado de Asturias, 179 p.

Jiménez-Sánchez, M., Domínguez-Cuesta, M.J., Aranburu, A., and Martos, E., 2011, Quantitative indexes based on geomorphologic features: A tool for evaluating human impact on natural and cultural heritage in caves: Journal of Cultural Heritage, v. 12, p. 270-278, doi:10.1016/j.culher.2011.01.004.

Jordá Cerdá, F., and Mallo Viesca, M., 1972, Las pinturas de la cueva de Las Herrerías (Llanes, Asturias): Revista de la Facultad de Filología Seminario de Prehistoria y Arqueología de la Universidad de Salamanca, v. 23, p. 306-311.

Kepa, T., 2001, Karst conservation in Slovenia: Acta Carsologica, v. 30, no. 1, p. 143-164.

Lera, T., 2009, The Virginia Cave Protection Act: A review (1966-2009): Journal of Cave and Karst Studies, v. 71, no. 3, p. 204-209.

Margat, J., 1968, Vulnérabilité des nappes d'eau souterraine à la pollution: Bases de la cartographie: Orléans, France, Bureau de Recherches Géologiques et Miniéres, Document 68 SGL 198 HYD.

Marín, A.I., Andreo, B., Jiménez-Sánchez, M., Domínguez, M.J., and Meléndez, M., 2010, Delimitación del perímetro de protección de la cueva de Herrerías (Llanes, Asturias) mediante el método $\mathrm{COP}+\mathrm{K}$, in Proceedings, III Congreso Español sobre Cuevas Turísticas, CUEVATUR 2010: Cuevas: patrimonio, naturaleza, cultura, y turismo: Aracena (Huelva). Spain, p. 451-464.

Marquínez, J., 1989, Síntesis cartográfica de la Región del Cuera y de los Picos de Europa: Trabajos de Geología, v. 18, p. 137-144.

Ortuño, A., Meléndez, M., and Rodríguez, M.L., 2004, Relación entre litología y características hidroquímicas de las aguas subterráneas: Red de Control de la Calidad del Principado de Asturias: Boletín Geológico y Minero, v. 115, no. 1, p. 35-46.

Pulido-Bosch, A., Martín-Rosales, W., López-Chicano, M., RodríguezNavarro, C., and Vallejos, A., 1997, Human impact in a tourist karstic cave (Aracena, Spain): Environmental Geology, v. 31, no. 3-4, p. 142-149, doi:10.1007/s002540050173. 
Ravbar, N., and Goldscheider, N., 2007, Proposed methodology of vulnerability and contamination risk mapping for the protection of karst aquifers in Slovenia: Acta Carsologica, v. 36, no. 3, p. 397-411.

Sánchez, M.A., Foyo, A., Tomillo, C., and Iriarte, E., 2007, Geological risk assessment of the area surrounding Altamira Cave: A proposed natural Risk Index and Safety Factor for protection of prehistoric caves: Engineering Geology, v. 94, p. 180-200, doi:10.1016/j.enggeo.2007.08.004.

Sánchez-Moral, S., Cañaveras, J.C., Soler, V., Saiz-Jiménez, C., Bedoya, J., and Lario, J., 2002, La conservación del monumento, in Lasheras, J.A., ed., Redescubrir Altamira: Madrid, Tuner Ediciones, p. 245-257.

SC.85 /CONF.008 /09, United Nations Educational, Scientific and Cultural Organization. $9^{\text {th }}$ session of the Committee, Paris, France, 2-6 December 1985, 09 COM XA - Inscription: Altamira Cave (Spain), 23 p.

Vías, J.M., Andreo, B., Perles, M.J., Carrasco, F., Vadillo, I., and Jiménez, P., 2006, Proposed method for groundwater vulnerability mapping in carbonate (karstic) aquifers: the COP method: Application in two pilot sites in Southern Spain: Hydrogeology Journal, v. 14, no. 6, p. 912-925, doi:10.1007/s10040-006-0023-6.

WHC-08/32.COM/24Rev, 2009, Decisions adopted at the 32nd session of the World Heritage Committee, Convention Concerning the Protection of the World Cultural and Natural Heritage. (Quebec City, 2008): Paris, UNESCO World Heritage Centre, 230 p.

Zaporožec, A., 1994, Concept of groundwater vulnerability, in Vrba, J., and Zaporožec, A., eds., Guidebook on mapping groundwater vulnerability: Hanover, Heinz Heise, International Contributions to Hydrogeology 16 , p. 3-8.

Zwahlen, F., ed., 2004, COST Action 620. Vulnerability and Risk Mapping for the Protection of Carbonate (Karstic) Aquifers: Final Report. Brussels, European Commission, Directorate-general XII Science, Research and Development, 297 p. 